\title{
Incineration of Textile Sludge for Partial Replacement of Cement in Concrete Production: A Case of Ethiopian Textile Industries
}

\author{
Esubalew Kasaw $\mathbb{D}^{1,2}$ Zelalem Adane ${ }^{1 D},{ }^{3}$ Gemeda Gebino $\left(\mathbb{D},{ }^{1}\right.$ Nakachew Assefa $\left(\mathbb{D},{ }^{2}\right.$ \\ Abera Kechi, ${ }^{1}$ and Ketema Alemu $\left(\mathbb{1}^{4}\right.$ \\ ${ }^{1}$ Textile Chemistry Research and Innovation Center, Ethiopian Institute of Textile and Fashion Technology, \\ Bahir Dar University, Bahir Dar, Ethiopia \\ ${ }^{2}$ Faculty of Civil and Water Resources Engineering, Bahir Dar Institute of Technology, \\ Bahir Dar University, Bahir Dar, Ethiopia \\ ${ }^{3}$ Textile Production Research and Innovation Center, Ethiopian Institute of Textile and Fashion Technology, \\ Bahir Dar University, Bahir Dar, Ethiopia \\ ${ }^{4}$ Apparel Production Research and Innovation Center, Ethiopian Institute of Textile and Fashion Technology, \\ Bahir Dar University, Bahir Dar, Ethiopia
}

Correspondence should be addressed to Esubalew Kasaw; esubalewtsega@gmail.com

Received 7 March 2021; Revised 20 April 2021; Accepted 5 May 2021; Published 15 May 2021

Academic Editor: Robert Černý

Copyright (c) 2021 Esubalew Kasaw et al. This is an open access article distributed under the Creative Commons Attribution License, which permits unrestricted use, distribution, and reproduction in any medium, provided the original work is properly cited.

The rapid growth of textile industries in Ethiopia plays an important role in economic development. However, the sludge from these wastewater treatment plants, which is not an integral part of the treatment process, is often considered hazardous as it is contaminated with heavy metals of dyestuffs and chemicals. The customary transfer routines such as landfilling and incineration may not be suitable because the leachate from the landfilling destinations and the buildups from the incinerators lead to optional contamination. Moreover, such transfer choices are not financially practical. Therefore, there is a growing need to look for various applications of sludge handling for sustainable development. This study attempts to find out an environmentally friendly solution for the management of the textile sludge by incinerating the sludge and using it for partial replacement of cement in concrete production. Concrete is a composite material formed by the combination of cement, sand, coarse aggregate, and water in a particular proportion so that concrete produced meets the needs regarding its workability, strength, durability, and economy. Typical textile sludge was having high heavy metal contents as per the United States Environmental Protection Agency (USEPA) guideline and should be properly disposed of. The sludge upon incineration at $625^{\circ} \mathrm{C}$ for four hours gives $78.1 \%$ moisture content, $61.2 \%$ volatile organic matter, and 59.6\% inorganic ash content. The main reactive oxide elements such as $\mathrm{SiO}_{2}, \mathrm{Fe}_{2} \mathrm{O}_{3}, \mathrm{CaO}$, and $\mathrm{Al}_{2} \mathrm{O}_{3}$ were found to be $18.51,3.19,23.87$, and $12.73 \%$ by weight in the ash. The calorific value determined from the dried sludge were found to be $1973 \mathrm{cal} / \mathrm{gm}$. Concrete block was manufactured by replacement of cement with $10,20,30,40$, and $50 \%$ incinerated textile sludge ash, and the manufactured block was evaluated in terms of their compressive strengths, leaching behavior, and water absorption. The replacement cement by the ash increases the hydration time reduced, and up to $20 \%$, sludge ash incorporation in the concrete mix design gives the designed compressive strength. Eventhough water absorption increases with increasing content of the incorporation of the ash, for the $20 \%$ replacement of cement, the lethal concentration of heavy metals was obtained to be below the permissible limit set by USEPA. Consequently, the experiment work indicates that the potential use of textile sludge ash for cement concrete gives the possibilities of reduction of heavy metal contamination to surroundings upon sludge disposal, reduces the use of raw materials for producing cement and reduces environmental pollution during cement production. 


\section{Introduction}

Industry is vital to the economies of modern societies and is an indispensable means of growth. Ethiopia is in a state of transformation from an agriculture-based economy to an industry-based economy. As a result, several industries are growing from time to time. The textile industry covers the largest foreign currency earnings nowadays in Ethiopia [1]. It has a major impact not only on the nation's economy but also on the economic and environmental quality of life [2]. Textile industries are one of the major consumers of water and dispose off a huge volume of effluent to the environment unless treated $[3,4]$. Sludge is an inevitable by-product discharged from wastewater treatment plants. It is hazardous as it is often contaminated with heavy metals of dyestuffs, solvents, surfactants, and chemicals $[5,6]$. The transfer of sludge stands out amongst the most difficult natural issues in wastewater treatment methods.

Several sludge-processing techniques are employed to treat textile mill sludge. Anaerobic digestion and aerobic digestion of sludge are one means of sludge processing; however, this process generates a great quantity of sludge that is formed by the excess of biomass and substances that were not degraded during the biological treatment $[7,8]$. Composting is another option of textile mill sludge processing, but sufficient digestion is not obtained as the sludge is not conducive for microorganisms and the biologically inert components of sludge remain undigested. Direct composting is not suitable for crop plants as plants get nutrients as well as toxic substances from direct composting of sludge [9]. In the past decades, sludge was mainly disposed of in landfills [6] and the seas [10]. However, space limitations on existing landfills [11] as well as increasing environmental concerns such as groundwater pollution from landfill leachate [12], effects on the marine environment [13], odor emission, and soil contamination have urged further investigation on various disposal methods. Application of textile mill sludge in agriculture has become difficult for fertilizer as standardization of the quality is difficult [14-16]. Agricultural use of sludge has been studied; however, the presence of heavy metals and $\mathrm{pH}$ of the sludge adjusts the soil qualities, and its effect restricts the use of sludge for agricultural purposes. An attempt also has been done to reuse the sludge in construction materials [17-20].

The application of textile effluent sludge without proper management may have adverse impacts on human health and the environment. One of the most common textile sludge disposal alternatives is incineration [21]. Textile sludge ash has been used as an additive and substitutive ingredient in cement-based materials [22-24], blocks [5], and bricks $[21,25,26]$. However, the properties of sludge are varied from factory to factory due to the difference in use and dosage of the dye molecule, water, and chemical impurities utilized in the manufacturing process, and the type and level of wastewater treatment differ among factories.

Hence, this study was aimed at characterizing the raw textile sludge obtained in selected textile industries in Ethiopia and incinerated ash for the replacement of cement in the mix design of the concrete production. As per the results, up to $20 \%$ cement substitution was achieved.

\section{Materials and Methods}

\subsection{Materials}

2.1.1. Textile Sludge. Textile mill sludge was collected from Bahir Dar Textile Share Company and Kombolcha Textile Share Company, Amhara, Ethiopia, in the dumping area of sludge from those textile industries whose primary products were dyed and printed $100 \%$ cotton products. These factories are integrated textile mills comprising spinning, weaving, and wet processing, and they do have wastewater treatment plants. An amount of $2.5 \mathrm{~kg}$ sludge was collected in the sludge drying bed of those companies using a plastic bag and stored in a dry storeroom every two weeks for a year. Sludge waste was then thoroughly mixed to get a homogenous sample and air-dried before experimentation. The sludge was oven-dried at $100^{\circ} \mathrm{C}$ for 24 hours to remove the excess moisture so that it does not affect the incineration process. Following the drying of the sludge, it was incinerated using a muffle model- 48000 at a temperature of $625^{\circ} \mathrm{C}$ for about 4 hours $[21,27,28]$. The resulting ash was then grinded into fine particles in powder form before it was mixed with concrete mix ingredients. The fine ash was sieved using a sieve shaker with a $150 \mu \mathrm{m}$ sieve, and only ash passing this sieve size was used for mix design.

2.1.2. Cement. Ordinary Portland cement (OPC), grade 42.5 as per ASTM C 150 depending upon the strength of the cement at 28 days, was used for this work.

2.1.3. Fine Aggregate. Locally available fine aggregates with a fineness module of 2.95 as per ASTM C-136 and a specific gravity of 2.63 as per ASTM C-128 with water absorption of $3.53 \%$ were collected from Pawi Andreb, Amhara, Ethiopia. The silt content of the fine aggregate was $3.21 \%$ as per ASTM $\mathrm{C} 87 \mathrm{M}$ and the organic impurities were class II as per ASTM C 33-03.

2.1.4. Coarse Aggregate. Locally available $37.5 \mathrm{~mm}$ down size coarse aggregate with a fineness module of 3.62 as per ASTM C-136a and specific gravity of 2.62 as per ASTM C-127, which has a flakiness index of $30.13 \%$ with water absorption of $1.54 \%$, were obtained from Addis Zemen, Amhara, Ethiopia.

2.1.5. Water. The water that was used in the mixing of concrete and curing of the specimen was free from organic and inorganic impurities, soluble salt, sulfate, and silt with a $\mathrm{pH}$ of 7 and conforming to IS 456-2000.

\section{Methods}

In this project work, once the sludge was collected from the ETP (effluent treatment plant) sludge drying bed of typical textile industries, the physio-chemical properties of sludge 
were first characterized to design appropriate method and condition of incineration. Then, the sun-dried and ovendried sludge was thermally processed by incineration. Upon incineration, the volatile matters were removed as a char and the inorganic materials were obtained in the form of ash, and the resulting ashes were characterized. Based on the information gained on the ash, a portion of cement was replaced by the ash in the concrete mix-design preparation and manufacturing. Lastly, the properties of concrete such as compressive strength and water absorption were assessed to evaluate the performance. The method followed under these works is illustrated in Figure 1.

3.1. Proximity Analysis. The proximity analysis was done by incineration of the sludge using a 48000-muffle furnace. The analysis was done following ASTM E871-82 for moisture content, ASTM E872-82 for volatile organic matter, and ASTM D1102-84 for ash content. The calorific value of textile sludge was determined using an adiabatic oxygen bomb calorimeter (1241EF, PARR MOLINE ILLINOISE, USA) following ASTM D 2015-96 test methods.

3.2. Heavy Metals on Sludge. The heavy metal analysis was conducted using Flame Atomic Absorption Spectrophotometry (PG 990, FAAS Hydride, and cold Hg technique, Germany). The organic matrix of the sludge was incinerated and the sample was prepared from the remaining ash using the acid dilution method. Hence, to free organic matter interferences of sludge for both row and incinerated ash, the specimens were digested using nitric acid.

3.3. Physio-Chemical Analysis of Textile Mill Sludge. The chemical composition of sludge was determined employing X-ray fluorescence (Thermo Fisher ARL 9900, United States) using ASTM test method C 114. After incineration, the specific gravity of textile mill sludge ash was determined as per ASTM C188 employing a laboratory pycnometer.

3.4. Mix Design of Concrete. Once the standard tests are done for confirmation of characteristics of mix ingredients, concrete strength of C-25 with a mix ratio of $1: 1.5: 3.5$ with a gauge box size of $18 \mathrm{~mm} * 40 \mathrm{~mm} * 50 \mathrm{~mm}$ was cast to find out the compressive strength of concrete. Different concrete cubes of C-25 strength of concrete were also cast by partial replacement of cement by incinerated ash of textile sludge. Concrete block was manufactured by blending the ash with cement and the content of the ash was $10 \%, 20 \%, 30 \%, 40 \%$, and $50 \%$, respectively. A 0.5 water-cement ratio was used. To account for the variations in the laboratory and the site exposure condition, a safety margin of $1.5 \%$ is considered in all trial baches.

3.5. Compressive Strength of Concrete. Compressive strength tests were conducted after 7, 14, and 28 days of moist curing following the procedures described in ASTM C 39.
3.6. Leaching Test. To know the concentration of the toxicity of heavy metals leached out from the concrete, a leaching test was conducted for a 28 day cured concrete employing the ICP-OES analysis examination method as per EN 13657-2002.

3.7. Water Absorption Test. For the water absorption test, the concrete cube size $150 \mathrm{~mm}$ was dried at $105^{\circ} \mathrm{C}$ in an oven and then put in desiccators to cool down to room temperature, and the dry weight was recorded as $w_{1}$. Then, the dry sample was immersed in water for 48 hours, and the specimens were taken out and wiped with a cloth and the weight of the specimen in wet condition was recorded as $w_{2}$. The percentage of water absorption was calculated as

$$
\text { water absorption }(\%)=\frac{(W 2-W 1)}{W 1} * 100 \text {. }
$$

\section{Result and Discussion}

4.1. Physio-Chemical Properties of Sludge and Ash. The heavy metals in row sludge and incinerated ash are tabulated in Table 1. The presence of heavy metals on ETP sludge was assumed to originate from dyes, pigments, surfactants, and other auxiliaries in wet processing processes [29]. High concentrations of heavy metals were obtained in the sludge after incineration. This increase in the concentration of metals may be associated with particulates forming free metals upon incineration. The ETP sludge has high heavy metal contents as per USEPA guidelines and should be properly disposed of. The incinerated ash of textile sludge was having a specific gravity of 2.73 .

The average value of three replicates of each test for the oxide composition of textile sludge ash and OPC is presented in Table 2. The main reactive oxide elements such as $\mathrm{SiO}_{2}, \mathrm{Fe}_{2} \mathrm{O}_{3}, \mathrm{CaO}$, and $\mathrm{Al}_{2} \mathrm{O}_{3}$ are present in different quantities where the former three are higher in OPC and the latter one is higher in textile sludge ash. The origin of these oxides may be associated with the chemicals and auxiliaries used in the production process and by the chemicals used in the wastewater treatment plant process as a coagulant and flocculants [30]. As per ASTM C125, the existence of such amount oxides in the textile mill sludge ash plays a highly important role in the property of binding and cohesion properties to replace the cement to a certain extent.

The proximate analysis was done three times and the average values are recorded in Table 3. The test result shows that the sludge does have a high amount of inorganic component accounted $56.9 \%$ in the form of ash [30,31].

The heating value of the sludge was found to be $1973 \mathrm{cal} /$ gm. The presence of organic chemical compounds may be helping in lowering heat energy to this level [32].

4.2. Compressive Strength of Concrete. The compressive strength of the concrete is measured, as shown in Figure 2, and observed to decrease with the incorporation of more textile sludge ash to replace the cement. Five replicates were tested for each specimen and the average values were 


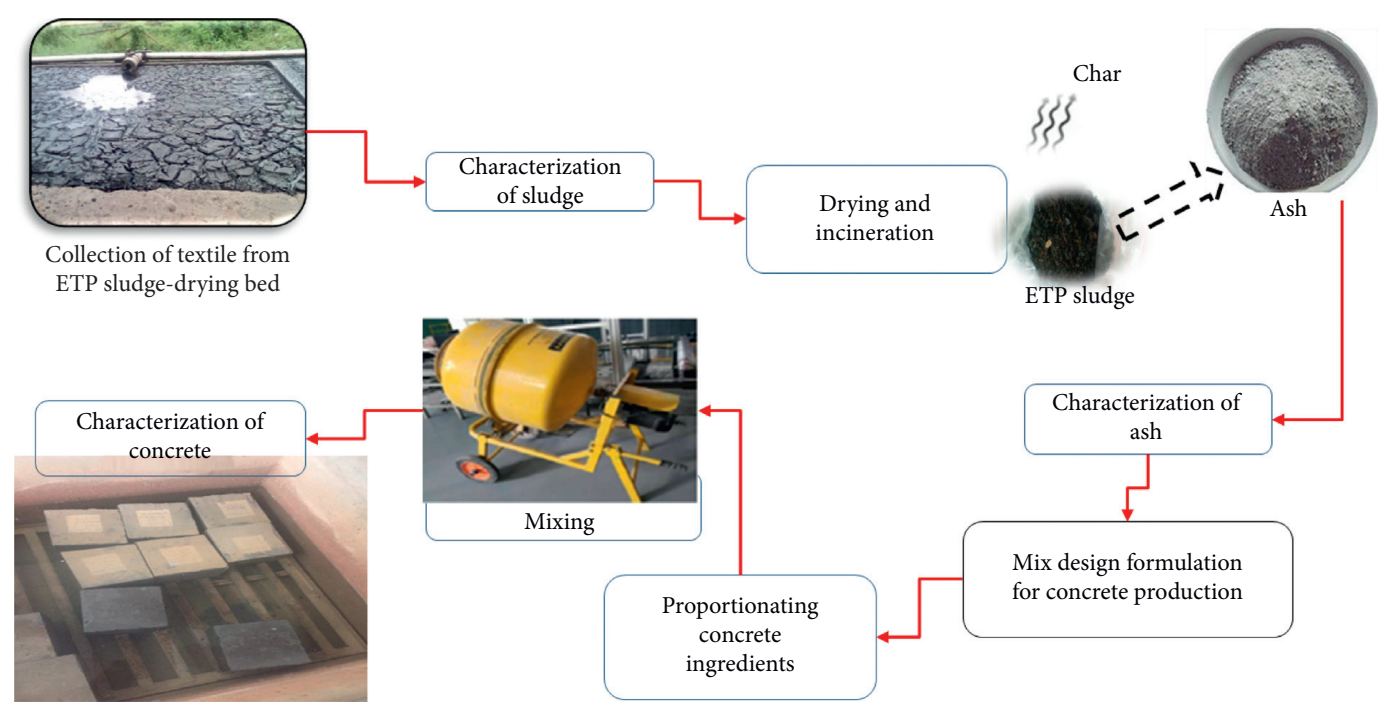

Figure 1: General work steps of the project.

TABLE 1: Heavy metals on the sludge.

\begin{tabular}{lcc}
\hline Heavy metals $(\mathrm{mg} / \mathrm{l})$ & Row sludge & Incinerated ash at $625^{\circ} \mathrm{C}$ \\
\hline $\mathrm{Cu}$ & 6.23 & 7.31 \\
$\mathrm{Fe}$ & 284 & 286.3 \\
$\mathrm{Mg}$ & 3.12 & 4.03 \\
$\mathrm{Ca}$ & 2.8 & 3.7 \\
$\mathrm{~Pb}$ & 1.79 & 1.5 \\
$\mathrm{Zn}$ & 41.73 & 44.17 \\
$\mathrm{Si}$ & 172.47 & 181.82 \\
$\mathrm{Cr}$ & 7.23 & 5.53 \\
$\mathrm{Cd}$ & 33.42 & 33.40 \\
$\mathrm{Ni}$ & 0.49 & 0.47 \\
$\mathrm{Mn}$ & 5.83 & 5.81 \\
\hline
\end{tabular}

TABle 2: Chemical composition of textile sludge ash and cement.

\begin{tabular}{lcc}
\hline Oxides (content by weight \%) & Textile sludge ash & OPC \\
\hline $\mathrm{Fe}_{2} \mathrm{O}_{3}$ & 3.19 & 3.71 \\
$\mathrm{MgO}$ & 1.79 & 1.53 \\
$\mathrm{Al}_{2} \mathrm{O}_{3}$ & 12.73 & 4.56 \\
$\mathrm{CaO}$ & 23.87 & 64.07 \\
$\mathrm{SiO}_{2}$ & 18.51 & 19.39 \\
$\mathrm{SO}_{3}$ & 9.33 & 3.93 \\
$\mathrm{Na}_{2} \mathrm{O}$ & 2.36 & 0.04 \\
$\mathrm{~K}_{2} \mathrm{O}$ & 0.31 & 0.66 \\
Loss on ignition & 3.47 & 1.65 \\
\hline
\end{tabular}

reported in Table 4. Replacing the cement by $10 \%, 20 \%, 30 \%$, $40 \%$, and $50 \%$ with the ash of textile mill sludge reduced the compressive strength of the resulting concrete by $4.8 \%, 9.1 \%$, $12.5 \%, 16.07 \%$, and $17.3 \%$, respectively.

This might be due to the small quantities of reactive oxides in the textile sludge ash so that strength of cement binder is reduced when the extent of replacement of cement with textile sludge ash is higher [33].

The replacement of cement in ETP ash increases the hydration time. This is most likely due to the presence of small quantity of oxides present in the ash compared with cement.
TABLE 3: Proximate test result.

\begin{tabular}{lc}
\hline Parameters & Percentage value \\
\hline Moisture content & 78.1 \\
Volatile organic matter & 61.2 \\
Ash content & 56.9 \\
\hline
\end{tabular}

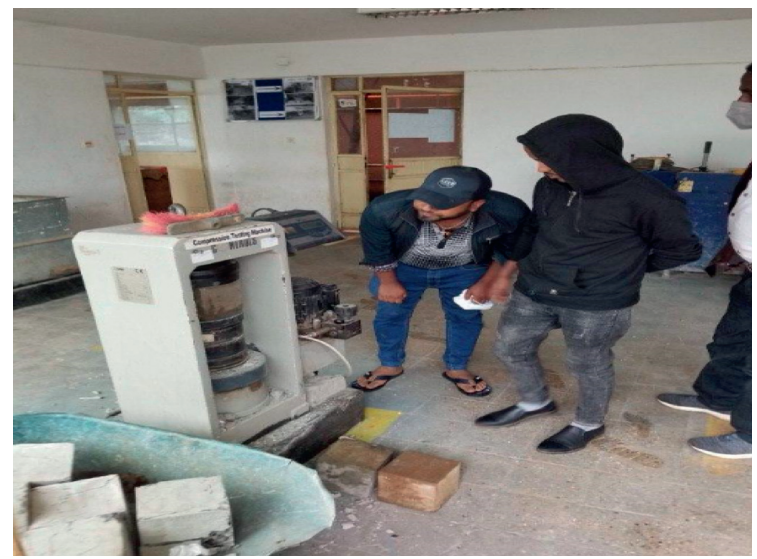

FIGURE 2: Compressive strength test.

The grade of concrete construction is selected based on structural design requirements as per BS 8500 standard test method [34-37]. Nominal mixes for grades of concrete such as C-15, C-20, and C-25 are generally used for small-scale construction. Large structures have high strength requirements; thus, they go for higher grades of concrete such as C-30 and above. The result obtained from Table 4 gives a comparative substitution of concrete as per BS 8500 .

4.3. Leaching and Water Absorption. The leachability of heavy metals was tested for a $20 \%$ incorporation of ash and is reported in Table 5. The amount of all the parameters of heavy metals obtained is within the permissible limit set by the USEPA standard. 
TABLE 4: Compressive strength of concrete cubes using different cement replacements.

\begin{tabular}{|c|c|c|c|c|}
\hline \multirow[t]{2}{*}{ Percentage replacement of cement by the ash of textile mill sludge } & \multicolumn{3}{|c|}{$\begin{array}{l}\text { Compressive strength on cubes } \\
\text { sample }\left(\mathrm{N} / \mathrm{mm}^{2}\right)\end{array}$} & \multirow[t]{2}{*}{ Water absorption (\%) } \\
\hline & 7 days & 14 days & 28 days & \\
\hline 0 & 25.2 & 33.6 & 42.00 & 6.41 \\
\hline 10 & 24.16 & 31.16 & 39.97 & 10.21 \\
\hline 20 & 23.34 & 29.07 & 38.17 & 12.49 \\
\hline 30 & 18.36 & 27.43 & 36.72 & 14.55 \\
\hline 40 & 15.23 & 25.82 & 35.25 & 16.43 \\
\hline 50 & 14.86 & 23.77 & 34.73 & 20.38 \\
\hline
\end{tabular}

TABLE 5: Leach analysis results.

\begin{tabular}{lcc}
\hline $\begin{array}{l}\text { Heavy metals } \\
(\mathrm{mg} / \mathrm{L})\end{array}$ & Leach amount & USEPA concentration limit \\
\hline $\mathrm{Cu}$ & 0.021 & 100 \\
$\mathrm{Mn}$ & 0.072 & 260 \\
$\mathrm{Cd}$ & 0.001 & 1 \\
$\mathrm{~Pb}$ & 0.037 & 5 \\
$\mathrm{Zn}$ & 1.520 & 500 \\
$\mathrm{Cr}$ & 0.031 & 5 \\
$\mathrm{Ni}$ & 0.025 & 1.3 \\
$\mathrm{Hg}$ & 0.001 & 0.2 \\
$\mathrm{As}$ & 0.001 & 5 \\
\hline
\end{tabular}

The water absorption of the average value of three replicates for each specimen is tabulated in Table 4. As the percentage replacement of cement with textile sludge ash increases, the water absorption also increases. This may show that the degree of porosity and water absorptivity will increase with an increase of percentage replacement $[38,39]$. This increase in water absorption may result in a decrease in the strength of the concrete.

\section{Conclusions}

The textile mill sludge discharged from Ethiopian textile industries is a practical problem. In the selected textile mills, a significant quantity of sludge is generated which possesses sludge management problems. From the current project, it is confirmed that the quantity of heavy metals accumulated in sludge is beyond the permissible limit set by USEPA and pollutes the environment unless properly managed. The current approach was to utilize textile waste sludge for cement replacement after incineration which is an alternative and relatively safe method of sludge disposal mechanism over the prior arts. Different sludge ash to cement ratios were used to make sludge ash integrated concrete, and the properties of the concrete were assessed in comparison with the blank sample. The characteristics of concrete are influenced as the percentage of substitution increases, as compressive strength decreases and water absorption increases, and up to $20 \%$ cement replacement provides a sound replacement. The leaching test revealed a very low amount of heavy metals released from the cube samples at this amount of replacement; this was marginal as compared to the required heavy metal concentration causing cellular cytotoxicity [26]. As a result, sludge ash in concrete cubes can be used without posing a significant risk of heavy metal pollution. According to the current research, the resulting composite concrete can be used for nonstructural applications per BS 8500 standard. These findings suggest that if dumped in the open, textile sludge may be hazardous to human health and the environment. Textile sludge can be used to manufacture regular and quality concrete with a $20 \%$ cement substitute, as well as have ecologically sound means of disposal, as a solution to this pressing issue.

To use it for structural applications, additional parameters of composite concrete typically bending and shear have to be tested and comparison has to be done with conventional concrete. Furthermore, the techno-economic feasibility of this project has to be detailed in the future phase of this project.

\section{Data Availability}

The data used to support the findings of this study are included within the article.

\section{Conflicts of Interest}

The authors declare that they have no conflicts of interest.

\section{Acknowledgments}

The financial supports for this project were from the Ethiopian Institute of Textile and Fashion Technology, Bahir Dar University, Amhara, Ethiopia.

\section{References}

[1] K. Khurana, "An overview of textile and apparel business advances in Ethiopia," Research Journal of Textile and Apparel, vol. 22, no. 1, 2018.

[2] S. Khan and A. Malik, "Environmental and health effects of textile industry wastewater," Environmental deterioration and human health, Springer, Berlin, Germany, pp. 55-71, 2014.

[3] P. C. Vandevivere, R. Bianchi, and W. Verstraete, "Review: treatment and reuse of wastewater from the textile wetprocessing industry: review of emerging technologies," Journal of Chemical Technology \& Biotechnology, vol. 72, no. 4, pp. 289-302, 1998.

[4] I. Bisschops and H. Spanjers, "Literature review on textile wastewater characterisation," Environmental Technology, vol. 24, no. 11, pp. 1399-1411, 2003.

[5] J. Balasubramanian, P. C. Sabumon, J. U. Lazar, and R. Ilangovan, "Reuse of textile effluent treatment plant sludge 
in building materials," Waste Management, vol. 26, no. 1, pp. 22-28, 2006.

[6] T. Karthik and R. Rathinamoorthy, "Recycling and reuse of textile effluent sludge," Environmental Implications of Recycling and Recycled Products, pp. 213-258, Springer, Berlin, Germany, 2015.

[7] A. Kunz, P. Peralta-Zamora, S. G. d. Moraes, and N. Durán, "Novas tendências no tratamento de efluentes têxteis," Química Nova, vol. 25, no. 1, pp. 78-82, 2002.

[8] S. H. Lin and C. F. Peng, "Continuous treatment of textile wastewater by combined coagulation, electrochemical oxidation and activated sludge," Water Research, vol. 30, no. 3, pp. 587-592, 1996.

[9] A. Guha, O. Rahman, S. Das, and M. Hossain, "Characterization and composting of textile sludge," Resources and Environment, vol. 5, no. 2, pp. 53-58, 2015.

[10] A. Lara, C. Andreoli, and E. Pegorini, Environmental Impact Assessment and Monitoring of Final Sludge Disposal, Sludge Treatment and Disposal, IWA Publishers, London, UK, 2007.

[11] R. Blackburn, Biodegradable and Sustainable Fibres, Elsevier, Amsterdam, Netherlands, 2005.

[12] J. Wiszniowski, J. Surmacz-Górska, D. Robert, and J.-V. Weber, "The effect of landfill leachate composition on organics and nitrogen removal in an activated sludge system with bentonite additive," Journal of Environmental Management, vol. 85, no. 1, pp. 59-68, 2007.

[13] G. E. Walsh, L. H. Bahner, and W. B. Horning, "Toxicity of textile mill effluents to freshwater and estuarine algae, crustaceans and fishes," Environmental Pollution Series A, Ecological and Biological, vol. 21, no. 3, pp. 169-179, 1980.

[14] R. A. Milne and D. N. Graveland, "Sewage sludge as a fertilizer," Canadian Journal of Soil Science, vol. 52, no. 2, pp. 270-273, 1972.

[15] L. E. De-Bashan and Y. Bashan, "Recent advances in removing phosphorus from wastewater and its future use as fertilizer (1997-2003)," Water Research, vol. 38, no. 19, pp. 4222-4246, 2004.

[16] T. Maddumapatabandi, W. De Silva, and K. De Silva, Analysis of textile sludge to develop a slow releasing organic fertilizer, SAITM Research Symposium on Engineering Advancements, pp. 79-82, 2014.

[17] L. Świerczek, B. M. Cieślik, and P. Konieczka, "The potential of raw sewage sludge in construction industry-a review," Journal of Cleaner Production, vol. 200, pp. 342-356, 2018.

[18] O. A. Johnson, M. Napiah, and I. Kamaruddin, "Potential uses of waste sludge in construction industry: a review," Research Journal of Applied Sciences, Engineering and Technology, vol. 8, no. 4, pp. 565-570, 2014.

[19] B. S. S. Begum, R. Gandhimathi, S. Ramesh, and P. Nidheesh, "Utilization of textile effluent wastewater treatment plant sludge as brick material," Journal of Material Cycles and Waste Management, vol. 15, no. 4, pp. 564-570, 2013.

[20] S. S. Jahagirdar, S. Shrihari, and B. Manu, "Reuse of textile mill sludge in burnt clay bricks," International Journal of Advanced Technology in Civil Engineering, vol. 2, no. 1, pp. 96-99, 2013.

[21] S. A. Iqbal, I. Mahmud, and A. K. M. A. Quader, "Textile sludge management by incineration technique," Procedia Engineering, vol. 90, pp. 686-691, 2014.

[22] M. M. Rahman, M. M. R. Khan, M. T. Uddin, and M. A. Islam, "Textile effluent treatment plant sludge: characterization and utilization in building materials," Arabian Journal for Science and Engineering, vol. 42, no. 4, pp. 1435-1442, 2017.
[23] M. G. Kulkarni, A. Dwivedi, and S. Jahgirdar, "Textile mill sludege as fine aggregate in concrete," Global Journal of Research in Engineering, vol. 12, no. 2-B, 2012.

[24] H. Patel and S. Pandey, "Evaluation of physical stability and leachability of Portland pozzolona cement (PPC) solidified chemical sludge generated from textile wastewater treatment plants," Journal of Hazardous Materials, vol. 207-208, pp. 56-64, 2012.

[25] S. S. Jahagirdar, S. Shrihari, and B. Manu, "Utilization of textile mill sludge in burnt clay bricks," International Journal of Environmental Protection, vol. 3, no. 5, 6 pages, 2013.

[26] T. B. Anwar, B. Behrose, and S. Ahmed, "Utilization of textile sludge and public health risk assessment in Bangladesh," Sustainable Environment Research, vol. 28, no. 5, pp. 228-233, 2018.

[27] S. C. Chin, D. Ing, A. Kusbiantoro, Y. K. Wong, and S. W. Ahmad, "Characterization of sewage sludge ASH (SSA) in cement mortar," ARPN: Journal of Engineering and Applied Sciences, vol. 11, no. 2242, e2247 pages, 2016.

[28] J. Oladejo, K. Shi, X. Luo, G. Yang, and T. Wu, "A review of sludge-to-energy recovery methods," Energies, vol. 12, no. 1, pp. 1-38, 2018.

[29] X. Zhang, J. Zhou, Z. Xu, P. Zhu, and J. Liu, “Characterization of heavy metals in textile sludge with hydrothermal carbonization treatment," Journal of Hazardous Materials, vol. 402, Article ID 123635, 2021.

[30] S. Goyal, R. Siddique, S. Jha, and D. Sharma, "Utilization of textile sludge in cement mortar and paste," Construction and Building Materials, vol. 214, pp. 169-177, 2019.

[31] S. Jeevanandam, K. Ravikumar, A. Das, and M. Goel, "Comprehensive study on textile dyeing sludge as a substitute for cement in cement-mortar," International Journal of Technology, vol. 5, no. 2, 2015.

[32] A. E. Zanoni and D. L. Mueller, "Calorific value of wastewater plant sludges," Journal of the Environmental Engineering Division, vol. 108, no. 1, pp. 187-195, 1982.

[33] S. Mahdinia, H. Eskandari-Naddaf, and R. Shadnia, "Effect of cement strength class on the prediction of compressive strength of cement mortar using GEP method," Construction and Building Materials, vol. 198, pp. 27-41, 2019.

[34] M. G. Alexander, M. Santhanam, and Y. Ballim, "Durability design and specification for concrete structures-the way forward," International Journal of Advances in Engineering Sciences and Applied Mathematics, vol. 2, no. 3, pp. 95-105, 2010.

[35] E. Allen and J. Iano, Fundamentals of Building Construction: Materials and Methods, John Wiley \& Sons, Hoboken, NJ, USA, 2019.

[36] M. L. Gambhir, Concrete Technology: Theory and Practice, Tata McGraw-Hill Education, NewYork, NY, USA, 2013.

[37] C. E. Reynolds, J. C. Steedman, and A. J. Threlfall, Reinforced Concrete Designer's Handbook, CRC Press, Boca Raton, FL, USA, 2007.

[38] Z. Farhana, H. Kamarudin, A. Rahmat, and A. Al Bakri, The Relationship between Water Absorption and Porosity for Geopolymer Paste, Materials Science Forum, Trans Tech Publications, Geneva, Switzerland, 2015.

[39] E. Prahara, Compressive Strength and Water Absorption of Pervious Concrete that Using the Fragments of Ceramics and Roof Tiles, EPJ Web of Conferences, EDP Sciences, Leis Ulis, France, 2014. 